\title{
HUBUNGAN ANTARA STIMULASI ALAT PERMAINAN EDUKATIF DENGAN PERKEMBANGAN MOTORIK KASAR DAN HALUS ANAK USIA PRE SCHOOL DI SEKOLAH TK KABUPATEN TEGAL
}

\author{
Feti Ariskha*Arista Adityasari Putri**Dwi Indah Iswanti** \\ Sekolah Tinggi Ilmu Kesehatan Karya Husada Semarang \\ Fetiarisca@gmail.com
}

\begin{abstract}
ABSTRAK
Kondisi Indonesia akhir tahun 2013, anak usia 4-6 tahun yang belum terlayani pendidikannya ada 13,0 juta $(63,46 \%)$ dari 17,6 juta. Hasil penelitian / kajian yang dilakukan oleh pusat kurikulum, balitbangnas menunjukkan bahwa hamper seluruh aspek perkembangan anak yang masuk Taman Kanak-Kanak mempunyai kemampuan yang lebih tinggi dari pada anak yang tidak masuk Taman Kanak-Kanak di kelas 1 Sekolah Dasar. Tujuan penelitian ini untuk mengetahui hubungan antara Alat Permainan Edukatif dengan perkembangan motorik kasar dan halus anak usia pre school di sekolah TK Kabupaten Tegal. Penelitian ini menggunakan kuantitatif, desain case control dengan pendekatan restrospective. Populasi responden sebanyak 130 responden dengan teknik proportionate stratified random sampling, jumlah sampel sebanyak 30 responden. Data yang diperoleh dianalisis secara univariat dan bivariat menggunakan uji chi square. Hasil menunjukkan stimulasi Alat Permainan Edukatif dengan perkembangan motorik halus p-value fisher exact $=0,026<0,05$ dan stimulasi Alat Permainan Edukatif dengan perkembangan motorik kasar p-value fisher exact $=0,002<0,05$. Ada hubungan antara stimulasi Alat Permainan Edukatif dengan perkembangan motorik halus dan kasar anak usia pre school.
\end{abstract}

Kata Kunci : Alat Permainan Edukatif, Perkembangan, Motorik Kasar, Motorik Halus, Anak usia pre school

\section{RELATIONSHIP BETWEEN EDUCATIONAL GAME STIMULATING WITH GROUND AND FINE MOTOR DEVELOPMENT OF PRE SCHOOL AGE CHILDREN IN TK SCHOOL, TEGAL REGENCY}

\begin{abstract}
Indonesia condition late 2013, children aged 4-6 years who have not served their education there are 13.0 million (63,46\%) from 17.6 million. Results of research / studies carried out by the central curriculum, balitbangnas shows that almost all aspect of child development that enter Kindergarten has a higher ability than children who do not attend kindergarten in grade 1 primary school. To determine the relationship between Games Educational tool with gross and fine motor development of pre-school age children in kindergarten Tegal. This study uses a quantitative, case control design with a retrospective approach. The population of respondents as many as 130 respondens with proportionate stratified random sampling, sample size of 30 respondents. Data were analyzed using univariate and bivariate using chi square test. Result showed stimulation games educational tool with fine motor development fisher exact p-value $=0.026<0.05$ and stimulation games educational tool with gross motor development fisher exact p-value $=0.002<0.05$. there is a relationship between stimulation games educational tool with the development of fine and gross motor pre-school age childreen.
\end{abstract}

Keywords : Games Educational Tool, Development, Motor Coarse, Fine motor skills, pre-school age children. 


\section{PENDAHULUAN}

Anak usia dini atau anak yang berada pada usia antara 0-6 tahun merupakan anak yang sedang membutuhkan upaya-upaya pendidikan untuk mencapai optimalisasi semua aspek perkembangan baik perkembangan fisik maupun psikis yang meliputi perkembangan intelektual, bahasa, motorik dan sosioemosional. Karena anak Taman Kanak-Kanak berada pada rentang usia 4-6 tahun, maka anak Taman Kanak-Kanak merupakan bagian dari anak usia dini. Setiap anak mempunyai potensi yang sangat penting untuk dikembangkan. Potensi tersebut meliputi moral, nilai-nilai agama, social, emosional, kognisi, bahasa, fisik atau motorik, kemandirian dan seni untuk siap memasuki pendidikan dasar (Gutama dalam Yulianti, 2010)

Kondisi Indonesia akhirtahun 2013, anakusia 4-6 tahun yang belum terlayani pendidikannya ada 13,0juta $(63,46 \%)$ dari 17,6 juta. Hasil penelitian / kajian yang dilakukan oleh pusat kurikulum, balitbangnas menunjukkan bahwa hampir seluruh aspek perkembangan anak yang masuk Taman Kanak-Kanak mempunyai kemampuan yang lebih tinggi dari pada anak yang tidak masuk Taman Kanak-Kanak di kelas 1 Sekolah Dasar. Angka mengulang kelas I dan II lebih tinggi dari yang lain. Data angka mengulang kelas tahun 2012/2013 untuk kelas 1 sebesar 10,85\%, kelas II sebesar 6,68\%, kelas III sebesar 5,48\%, kelas IV sebesar 4,28\%, kelas V sebesar 2,92\% dankelas VI 0,42\% (Depdiknas dalam Yulianti, 2010)

Program Stimulasi, Deteksidan Intervensi Dini Tumbuh Kembang (SDIDTK) merupakan revisi dari program Deteksi Dini Tumbuh Kembang (DDTK) yang telah dilakukan sejak tahun 1988 dan termasuk salah satu program pokok Puskesmas. Cakupan SDIDTK balita dan anak prasekolah Dinas Kesehatan Kota Semarang tahun 2006 adalah 58,7\% dan tahun 2007 adalah 65,91\%. Angka cakupan ini memang meningkat namun masih di bawah target Dinas Kesehatan Kota Semarang yaitu 59\% (tahun 2006) dan 68\% (tahun 2007) dan masih di bawah target sasaran Provinsi Jawa Tengah tahun 2007 yaitu 70\% (Maritalia, 2009, conclusion section, II xix,http://eprints.undip.ac.id, diperoleh tanggal 11 Agustus 2015). Di Kabupaten Tegal pelaksanaan PAUD/ TK baru menjangkau sebagian kecil masyarakat. Hal ini dapat dilihat dari persentase jumlah siswa TK/ RA yang baru mencapai sebesar 25,80\% pada tahun 2013. Jumlah ini menurun bila dibandingkan dengan tahun sebelumnya (BAPPEDA Kabupaten Tegal)

Alat Permainan Edukatif (APE) adalah alat permainan yang dapat mengoptimalkan perkembangan anak sesuai usia dan tingkat perkembangannya dan yang berguna untuk pengembangan aspek fisik, bahasa, kognitif, dan social anak (Soetjiningsih, 2005. Perkembangan anak tidak sama dengan pertumbuhannya. Keduanya (pertumbuhan dan 
perkembangan) memang benar saling berkaitan dan dalam penggunaan kedua pengertian tersebut sering kali dikacaukan satu sama lain. Bila pertumbuhan menjelaskan perubahan dalam ukuran, sedangkan perkembangan adalah perubahan dalam kompleksitas dan fungsinya (Patmonodewo, 2008)

Pengembangan aspek motorik dilakukan melalui kegiatan- kegiatan yang dapat menunjang atau merangsang pertumbuhan fisik anak, seperti belajar, berjalan atau merangkak, naik turun tangga, dan bersepeda. Pengembangan bahasa dilakukan melatih bicara dan menggunakan kalimat yang benar. Pengembangan aspek kognitif dilakukan dengan pengenalan suara, ukuran, bentuk, warna objek, dan lain-lainnya. Sementara pengembangan aspek social dilakukan dengan cara berhubungan atau berinteraksi dengan orang tua, saudara, keluarga, dan masyarakat (Nursalam, 2005)

Berdasarkan penelitian sebelumnya (Lucie dkk, 2006) yang berjudul "Hubungan antara Alat Permainan Edukatif dan Perkembangan Motorik Anak pada Taman Penitipan Anak", hasil penelitian ini menunjukkan ada perbedaan yang sangat bermakna dalam skor keterampilan motorik pada kelompok yang mendapatkan stimulasi dengan APE dan kelompok yang tidak mendapatkan stimulasi dengan APE.

Dari hasil survei yang dilakukan peneliti di TK Kabupaten Tegal rata-rata setiap kelasnya terdapat 15 siswa, usia 4-5tahun. Dari 15 siswa, hanya 10 anak yang bisa mewarnai dengan rapi. Pada kemampuan motorik kasarnya 8 anak mengangkat satu kaki dengan baik selama 4 detik, 7 anak lainnya hanya bisa mengangkat kaki selama 2 detik. Di TK tersebut Alat Permainan Edukatif yang sudah dilakukan adalah puzzle. Guru membongkar permainan puzzle tersebut kemudian anak-anak diminta untuk menyusun puzzle tersebut kemudian anakanak diminta untuk menyusun puzzle tersebut kemudian anak-anak diminta untuk menyusun puzzle tersebut sesuai dengan gambarnya. 1 puzzle terdiri dari 3 anak, namun hanya beberapa anak yg menyelesaikan permainan puzzle tersebut dengan baik sesuai dengan waktu yang ditentukan oleh guru. Berdasarkan uraian diatas dan fenomena yang terjadi dilapangan, peneliti tertarik untuk meneliti tentang "Hubungan Antara Stimulasi Alat Permainan Edukatif dengan Perkembangan Motorik Kasar dan Halus Pada Anak Usia Pre School di Sekolah TK Kabupaten Tegal"

\section{METODE PENELITIAN}

Penelitian ini menggunakan penelitian kuantitatif dengan desain survei kasus kontrol (Case Control), dan menggunakan pendekatan retrospective. Dengan kata lain, efek dari penyakit atau status kesehatan didefinisikan saat ini, kemudian faktor resiko diidentifikasi ada 
atau terjadinya pada waktu yang lalu. Populasi dalam penelitian ini adalah anak usia pre schoolberjumlah 130 siswa berada di TK Pertiwi Margapadang, TK Pertiwi Kesamiran, dan TK Pertiwi Mangunsaren Kabupaten Tegal. Dalam penelitian ini pengambilan sampel di lakukan secara proportionate stratified random sampling yaitu suatu cara pengambilan sampel yang mempertimbangkan antara jumlah anggota populasi berdasar masing-masing strata dengan jumlah sampel sebanyak 30 anak.

\section{HASIL PENELITIAN}

\section{Tabel 1}

Distribusi Frekuensi Pemberian Stimulasi Alat Permainan Edukatif Anak Usia Pre School di Kabupatan Tegal

\begin{tabular}{|c|c|c|}
\hline Pemberian Stimulasi Alat Permainan & $\mathrm{n}$ & $\%$ \\
\hline Melakukan & 16 & 53,3 \\
\hline Tidak melakukan & 14 & 46,7 \\
\hline Jumlah & 30 & 100 \\
\hline
\end{tabular}

Berdasarkan Tabel 1 dapat diketahui bahwa hasil penelitian yang dilakukan pada anak usia pre school di Kabupaten Tegal dapat diketahui sebagian besar anak usia pre school mendapatkan stimulasi alat permainan edukatif yang melakukan sebanyak 16 responden $(53,3 \%)$.

Tabel 2. Distribusi Frekuensi Perkembangan Motorik Halus Anak Usia Pre School di Kabupatan Tegal

\begin{tabular}{|c|c|c|}
\hline Perkembangan Motorik Halus & $\mathrm{n}$ & $\%$ \\
\hline Normal & 16 & 53,3 \\
\hline Suspek & 11 & 36,7 \\
\hline Unstable & 3 & 10,0 \\
\hline Jumlah & 30 & 100 \\
\hline
\end{tabular}

Berdasarkan Tabel 2 dapat diketahui bahwa hasil penelitian yang dilakukan pada anak usia pre school di Kabupaten Tegal dapat diketahui sebagian besar anak usia pre school mengalami perkembangan motorik halus yang normal sebanyak 16 responden $(53,3 \%)$.

Tabel 3. DistribusiFrekuensiPerkembanganMotorikKasarAnakUsiaPre Schooldi KabupatanTegal

\begin{tabular}{|c|c|c|}
\hline Perkembangan Motorik Kasar & $\mathrm{N}$ & $\%$ \\
\hline Normal & 18 & 60,0 \\
\hline Suspek & 9 & 30,0 \\
\hline Unstable & 3 & 10,0 \\
\hline Jumlah & 30 & 100 \\
\hline
\end{tabular}


Berdasarkan Tabel 3 dapat diketahui bahwa hasil penelitian yang dilakukan pada anak usia pre school di Kabupaten Tegal dapat diketahui sebagian besar anak usia pre school mengalami perkembangan motorik kasar yang normal sebanyak 18 responden $(60 \%)$.

Tabel 4. Hubungan Antara Stimulasi Alat Permainan Edukatif dengan Perkembangan Motorik Halus Anak Usia Pre School di KabupatenTegal

\begin{tabular}{|c|c|c|c|c|c|c|c|c|c|c|}
\hline \multirow{3}{*}{$\begin{array}{l}\text { StimulasiAlatPer } \\
\text { mainanEdukatif }\end{array}$} & \multicolumn{6}{|c|}{ PerkembanganMotorikHalus } & \multirow{2}{*}{\multicolumn{2}{|c|}{ Total }} & \multirow{3}{*}{$\begin{array}{l}\text { Continuity } \\
\text { Correction }\end{array}$} & \multirow{3}{*}{$\begin{array}{c}\mathrm{P} \\
\text { Fisher } \\
\text { Exact }\end{array}$} \\
\hline & \multicolumn{2}{|c|}{ Normal } & \multicolumn{2}{|c|}{ Suspek } & \multicolumn{2}{|c|}{ Unstable } & & & & \\
\hline & $\mathrm{f}$ & $\%$ & $\mathrm{~F}$ & $\%$ & $\mathrm{f}$ & $\%$ & $\mathrm{f}$ & $\%$ & & \\
\hline Melakukan & 12 & 75,0 & 4 & 25,0 & 0 & 0,0 & 16 & 100 & 4,736 & 0,026 \\
\hline Tidak melakukan & 4 & 18,6 & 7 & 50,0 & 3 & 21,4 & 14 & 100 & & \\
\hline Jumlah & 16 & 53,3 & 11 & 36,7 & 3 & 10,0 & 30 & 100 & & \\
\hline
\end{tabular}

Berdasarkan Tabel 4 di atas maka dapat diketahui bahwa anak pre school di kabupaten Tegal yang melakukan stimulasi alat permainan edukatif sebagian besar mengalami perkembangan motorik halus yang normal sebanyak 12 responden (75\%). Hal ini berarti pemberian stimulasi Alat Permainan Edukatif berperan dalam perkembangan motorik halus anak usia pre school. Berdasarkan hasil Uji Continuity Correction dengan tingkat probabilitas $\alpha: 0,05$. Hasil olah data didapatkan nilai continuity correction sebesar 4,736 dengan $p$ value $0,026<0,05$. Berdasarkan criteria dapat dinyatakan hipotesa (Ho) diteirma dan Hipotesa (Ha) ditolak berarti terdapat hubungan antara pemberian stimulasi Alat Permainan Edukatif dengan perkembangan motorik halus anak usia pre school.

Tabel 5. Hubungan Antara Stimulasi Alat Permainan Edukatif Dengan Perkembangan Motorik Kasar Anak Usia Pre School

\begin{tabular}{|c|c|c|c|c|c|c|c|c|c|c|}
\hline \multirow{3}{*}{$\begin{array}{l}\text { Stimulasi alat } \\
\text { permainan } \\
\text { edukatif }\end{array}$} & \multicolumn{6}{|c|}{ Perkembangan motorik kasar } & \multirow{2}{*}{\multicolumn{2}{|c|}{ Total }} & \multirow{3}{*}{$\begin{array}{l}\text { Continuity } \\
\text { Correction }\end{array}$} & \multirow{3}{*}{$\begin{array}{c}\mathrm{P} \\
\text { Fisher } \\
\text { Exact }\end{array}$} \\
\hline & \multicolumn{2}{|c|}{ Normal } & \multicolumn{2}{|c|}{ Suspek } & \multicolumn{2}{|c|}{ Unstabel } & & & & \\
\hline & $\mathrm{f}$ & $\%$ & $\mathrm{~F}$ & $\%$ & $\mathrm{f}$ & $\%$ & f & $\%$ & & \\
\hline Melakukan & 14 & 87,5 & 2 & 12,5 & 0 & 0,0 & 16 & 100 & 8,788 & 0,002 \\
\hline Tidak melakukan & 4 & 28,6 & 7 & 50,0 & 3 & 21,4 & 14 & 100 & & \\
\hline Jumlah & 18 & 60,0 & 9 & 30,0 & 3 & 10,0 & 30 & 100 & & \\
\hline
\end{tabular}

Berdasarkan Tabel 5 di atas maka dapat diketahui bahwa anak pre school di kabupaten Tegal yang melakukan stimulasi alat permainan edukatif sebagian besar mengalami perkembangan motorik kasar yang normal sebanyak 14 responden (87,5\%). Hal ini menunjukkan bahwa stimulasi Alat Permainan Edukatif berperan dalam perkembangan motorik kasar pada anak usia pre school.

Berdasarkan hasil Uji Continuity Correction dengan tingkat probabilitas $\alpha$ : 0,05. Dari hasil olah data didapatkan nilai continuity correction sebesar 8,788 dengan $p$ value $0,002<$ 0,05. Berdasarkan criteria dapat dinyatakan hipotesa (Ho) diterima dan Hipotesa (Ha) ditolak 
berarti terdapat hubungan antara pemberian stimulasi Alat Permainan Edukatif dengan perkembangan motorik kasar pada anak usia pre school.

\section{PEMBAHASAN}

\section{Pemberian Stimulasi Alat Permainan Edukatif Anak Usia Pre School}

Hasil observasi dapat diketahui sebagian besar anak presekolah mendapatkan stimulasi alat permainan edukatif sebanyak 16 responden yang melakukan (53,3\%). Hal ini menunjukkan bahwa guru-guru di TK atau anak pre school di Kabupaten Tegal telah mengetahui manfaat dan keuntungan memberikan alat permainan yang mendidik kepada anak. Sedangkan bagi anak pre school yang belum diberikan stimulasi alat permainan edukatif hal ini dikarenakan keterbatasan sekolah atau tempat belajar anak prasekolah sehingga tidak atau belum mampu menyediakan alat permainan edukatif kepada anak pre school, sehingga anak-anak hanya bermain seadanya seperti prosotan, naik turun tangga, ayunan dan lain-lain.

Hasil penelitian ini sesuai dengan penelitian yang dilakukan oleh Permana, dkk (2006) tentang Hubungan antara alat permainan edukatif dan perkembangan motorik anak pada taman penitipan anak dengan hasil penelitian menunjukkan Ada perbedaan yang sangat bermakna dalam skor keterampilan motorik pada kelompok yang mendapatkan stimulasi dengan APE dankelompok yang tidakmendapatkanstimulasidengan APE.

\section{Perkembangan Motorik Halus}

Hasil penelitian dapat diketahui sebagian besar anak pre school mengalami perkembangan motorik halus yang normal sebanyak 16 responden (53,3\%). Hasil ini menunjukkan bahwa perkembangan motorik halus anak pre school ditunjukkan dengan perilaku dan perkembangan selama belajar dimana anak prasekolah sudah mampu menggunting mengikuti garis lurus dan melengkung ataupun zigzag, menempel stiker ditempat yang diminta, mengkoordinasi jari-jari tangan dan mata, menggambar, melukis, membentuk dengan bahan seperti lilin dan semacamnya, membuat bentuk segi empat dan menyelesaikan pasel 4 keping dan lain-lain.

Perkembangan motorik anak TK yaitu perubahan kemampuan motorik dari bayi sampai dewasa yang melibatkan berbagai aspek perilaku dan kemampuan motorik. Aspek perilaku dan perkembangan motorik saling mempengaruhi satu sama lainnya (Samsudin, 2008). Menurut Rismayanthi (2013) keterampilan motorik halus menyangkut koordinasi gerakan jari-jari tangan dalam melakukan berbagai aktifitas. Hasil penelitian ini sesuai dengan penelitian yang dilakuk an oleh Permana, dkk (2006) tentang Hubungan antara alat permainan 
edukatif dan perkembangan motorik anak pada taman penitipan anak dengan hasil penelitian menunjukkan Ada perbedaan yang sangat bermakna dalam skor keterampilan motorik pada kelompok yang mendapatkan stimulasi dengan APE dankelompok yang tidak mendapatkan stimulasi dengan APE.

\section{Perkembangan Motorik Kasar}

Hasil penelitian dapat diketahui sebagian besar anak prasekolah mengalami perkembangan motorik kasar yang normal sebanyak 18 responden (60\%). Hal ini ditunjukkan dengan perkembangan dan kemajuan selama belajar dimana anak pra sekolah sudah mampu berjalan dengan menggunakan tumit kaki, berjinjit, melompat tidak beraturan, dan berlari dengan baik, berdiri dengan satu kaki selama 5 detik atau lebih, menguasai keseimbangan dengan berdiri diatas balok 4 inci, tetapi mengalami kesulitan meniti balok selebar $5 \mathrm{~cm}$ tanpa melihat kakinya, menuruni tangga dengan kaki bergantian, dapat memperkirakan tempat kaki berpijak, melompat dengan aturan tempo yang memadai dan mampu memainkan permainanpermainan yang membutuhkan reaksi cepat, mulai mengkoordinasikan gerakan-gerakan pada saat memanjat atau berguling pada trampoline kecil (kain layar yang direntangkan untuk menampung acrobat dan menunjukkan kesadaran untuk menilai batas tingkah laku yang berbahaya dengan lebih baik, tetapi masih membutuhkan pengawasan dijalan atau perlindungan diri pada aktifitas yang penting.

Sujiono (2007) berpendapat bahwa gerakan motorik kasar adalah kemampuan yang membutuhkan koordinasi sebagian besar bagian tubuh anak.Gerakan motorik kasar melibatkan aktifitas otot-otot besar seperti otot tangan, otot kaki, dan seluruh tubuh anak. Perkembangan motorik kasar anak lebih dulu dari pada motorik halus, misalnya anak akan lebih dulu memegang benda-benda yang ukuran besar daripada ukuran yang kecil. Karena anak belum mampu mengontrol gerakan jari-jari tangannya untuk kemampuan motorik halusnya, seperti meronce, menggunting dan lain-lain.

Hasil penelitian ini sesuai dengan penelitian yang dilakukan oleh Sumini, dkk (2014) tentang hubungan pengetahuan orang tua tentang alat permainan edukatif (APE) dengan perkembangan anak pra sekolah usia 4-5 tahun di desa tapak kecamatan panekan kabupaten magetan dengan hasil penelitian menunjukkan Ada hubungan pengetahuan orang tua tentang alat permainan edukatif (APE) dengan perkembangan anak prasekolah usia 4-5 tahun. 


\section{Hubungan Antara Stimulasi Alat Permainan Edukatif dengan Perkembangan Motorik}

\section{Halus Anak Usia Pre School}

Hasil penelitian didapatkan ada hubungan anak pre school di kabupaten Tegal yang diberikan stimulasi alat permainan edukatif dan yang melakukan sebagian besar mengalami perkembangan motorik halus sebanyak 12 responden (75\%). Hal ini menunjukkan bahwa stimulasi Alat Permainan Edukatif memang penting untuk perkembangan motorik halus pada anak usia pre school.

Alat permainan merupakan salah satu alat untuk menstimulasi tumbuh kembang anak.Stimulasi adalah perangsangan yang datangnya dari lingkungan diluar individu anak. Anak yang mendapat stimulasi akan lebih cepat berkembang dari pada anak yang kurang mendapat stimulasi. Stimulasi juga berfungsi sebagai penguat. Contohnya dengan munculnya seseorang di depan anak misalnya ibunya, maka akan memberikan gairah kenikmatan dan kesenangan sehingga anak akan melakukan inisiatif untuk melakukan permainan dengan ibu tersebut untuk memperoleh kesenangan (Soetjiningsih, 2005).

Hasil penelitian ini sesuai dengan penelitian yang dilakukan oleh Kusnita (2010) tentang Hubungan kesempatan bermain, kebugaran tubuh, dan kemampuan menggunakan media balok dengan perkembangan dengan perkembangan motorik anak pada taman kanak kanak di kota medan dengan hasil penelitian menunjukkan terdapat hubungan positif yang signifikan antara kesempatan bermain dengan perkembangan motorik anak.

\section{Hubungan Antara Stimulasi Alat Permainan Edukatif dengan Perkembangan Motorik}

\section{Kasar Anak Usia PreSchool}

Hasil penelitian didapatkan ada hubungan anak pre school di kabupaten Tegal yang diberikan stimulasi alat permainan edukatif sebagian besar mengalami perkembangan motorik kasar yang normal sebanyak 14 responden (87,5\%). Hal ini menunjukkan bahwa stimulasi Alat Permainan Edukatif sangat penting dalam perkembangan motorik kasar anak usia pre school.

Pengembangan motorik kasar di TK bertujuan untuk memperkenalkan dan melatih gerakan kasar, meningkatkan kemampuan mengelola, mengontrol gerakan tubuh dan koordinasi, serta meningkatkan keterampilan tubuh dan cara hidup sehat, sehingga dapat menunjang pertumbuhan jasmani yang sehat, kuat dan terampil. Sesuai dengan tujuan pengembangan jasmani tersebut, anak didik dilatih gerakan-gerakan dasar yang akan membantu perkembangan motoriknya kelak (Depdiknas, 2008).

Fungsi pengembangan motorik kasar pada anak TK menurut Aisyah (2008) sebagai berikut melatih kelenturan dan koordinasi otot jari dan tangan, memacu pertumbuhan dan 
pengembangan fisik/motorik, rohani, dan kesehatan anak, membentuk, membangun, dan memperkuat tubuh anak, melatih keterampilan/ ketangkasan gerak dan berpikir anak, meningkatkan perkembangan emosional anak, meningkatkan perkembangan sosial anak dan menumbuhkan perasaan menyenangi dan memahami manfaat kesehatan pribadi.

Hasil penelitian ini sesuai dengan penelitian yang dilakukan oleh Permana, dkk (2006) tentang Hubungan antara alat permainan edukatif dan perkembangan motorik anak pada taman penitipan anak dengan hasil penelitian menunjukkan Ada perbedaan yang sangat bermakna dalam skor keterampilan motorik pada kelompok yang mendapatkan stimulasi dengan APE dan kelompok yang tidak mendapatkan stimulasi dengan APE.

\section{KESIMPULAN}

1. Anak pre school sebagian besar yang mendapatkan stimulasi Alat Permainan Edukatif dan melakukannya sebanyak 16 responden $(53,3 \%)$.

2. Anak pre school sebagian besar mengalami perkembangan motorik halus yang normal sebanyak 16 responden $(53,3 \%)$.

3. Anak pre school sebagian besar mengalami perkembangan motorik kasar yang normal sebanyak 18 responden $(60 \%)$.

4. Ada hubungan antara stimulasi Alat Permainan Edukatif dengan perkembangan motorik halus pada anak usia pre school di KabupatenTegal.

5. Ada hubungan antara stimulasi Alat Permainan Edukatif dengan perkembangan motorik kasar pada anak usia pre school di KabupatenTegal.

\section{SARAN}

1. Bagi Guru

Guru hendaknya memberikan stimulasi positif yang dapat mempercepat perkembangan otak anak sehingga perkembangan motorik kasar dan halus anak pre school dapat berkembang sesuai dengan usianya dan memberikan konseling kepada orang tua bukan hanya tentang pendidikan tetapi juga tentang kesehatan.

2. Bagi Orang Tua

Orang tua diharapkan mengerti tentang apa saja permainan yang dapat meningkatkan perkembangan motorik anak, bukan hanya tentang pendidikannya saja tetapi juga kesehatannya. 


\section{DAFTAR PUSTAKA}

Aisyah, Siti. 2008. Perkembangan Konsep Dasar Pengembangan Anak Usia Dini. Jakarta: Universitas Terbuka.

Depdiknas. 2008. Undang-Undang RI No. 20 Tahun 2003. Perkembangan Anak. Jakarta: Erlangga.

Kusnita, E. 2010. Hubungan Kesempatan Bermain, Kebugaran Tubuh, dan Kemampuan Menggunakan Media Balok dengan Perkembangan dengan Perkembangan Motorik Anak Pada Taman Kanak Kanak di Kota Medan.15-34.

Maritalia, 2009, conclusion section, II xix,http://eprints.undip.ac.id, diperoleh tanggal 11 Agustus 2015.

Nursalam. 2011. Konsep dan Penerapan Metodelogi Penelitian Ilmu Keperawatan. Jakarta: salemba medika.

Patmonodewo, S. 2008.PendidikanAnakPrasekolah. Jakarta : PT RinekaCipta.

Permana, dkk. 2006. Hubungan antara alat permainan edukatif dan perkembangan motorik anak pada taman penitipan anak, 39 (1), 27-34.

Samsudin.2008.PembelajaranMotorik di Taman Kanak-Kanak.Jakarta :Litera.

Soetjiningsih. 2005. TumbuhKembangAnakCetakanII.Jakarta : EGC

Sujiono, Yuliani Nurani. 2009. Konsep Dasar Pendidikan Anak Usia Dini. Jakarta: Idektif.

Sumini, dkk. 2014. Hubungan Pengetahuan Orang Tua Tentang Alat Permainan Edukatif (APE) dengan Perkembangan Anak Pra Sekolah Usia 4-5 tahun di Desa Tapak Kecamatan Panekan Kabupaten Magetan. Jurnal Delima Harapan, 2 (1), 24-31 